Bond University

Research Repository

\title{
A review of the 2011 construction survey and results from the World Bank International Comparison Program
}

Meikle, Jim

Published in:

Accounting for Construction: Frameworks, Productivity, Cost and Performance

Licence:

Other

Link to output in Bond University research repository.

Recommended citation(APA):

Meikle, J. (2019). A review of the 2011 construction survey and results from the World Bank International Comparison Program. In R. Best, \& J. Meikle (Eds.), Accounting for Construction: Frameworks, Productivity, Cost and Performance (pp. 155-180). Routledge.

\section{General rights}

Copyright and moral rights for the publications made accessible in the public portal are retained by the authors and/or other copyright owners and it is a condition of accessing publications that users recognise and abide by the legal requirements associated with these rights.

For more information, or if you believe that this document breaches copyright, please contact the Bond University research repository coordinator. 


\section{CHAPTER 9}

\section{A REVIEW OF THE 2011 CONSTRUCTION SURVEY AND RESULTS FROM THE WORLD BANK INTERNATIONAL COMPARISON PROGRAM}

\section{Jim Meikle}

\section{Introduction}

Making credible international price level comparisons is difficult. Commercial exchange rates do not necessarily reflect real differences in purchasing power between countries and a single currency convertor does not accurately represent price level differences across different components of an economy. The World Bank, through its International Comparison Program (ICP), is responsible for the production of Purchasing Power Parities (PPPs) for both national economies (Gross Domestic Product, GDP) and for sub-components of GDP for around 200 countries (see World Bank 2018a). PPPs are alternatives to market exchange rates and are intended to reflect price level differences across countries more accurately. One of the sub-components of GDP in the ICP is construction, part of Gross Fixed Capital Formation (GFCF) or investment.

The main components of GFCF are machinery and equipment, and construction. In terms of content and price levels these two are very different: machinery and equipment items are generally internationally traded and as a result are likely to have PPPs that are broadly similar to commercial exchange rates; the bulk of construction, on the other hand, is an essentially local activity and is likely to have PPPs that are markedly different to exchange rates or machinery and equipment PPPs. In poorer countries, construction price levels and, therefore, construction volumes are likely to be understated using exchange rates, while in richer countries, the opposite is often the case.

The history of the development of PPP theory and its application to construction is described, as is the evolution of the calculation methods for construction PPPs, in Best and Meikle (2015: see chapters 2-4).

Construction is described by the World Bank and other international agencies as 'comparison resistant'. According to the OECD Glossary of Statistical Terms, this is a term used to describe goods and services whose complexity, variation and country specificity make it difficult for them to be priced reliably across countries (OECD 2007). This is commented on 
throughout the chapter, but it is important to emphasize from the start that the calculation of PPPs for construction is problematic, much more so than it is for many other economic activities.

To date the ICP has undertaken regular but relatively infrequent international price surveys; the last two were in 2005 and 2011. In 2016, the United Nations Statistical Commission agreed that the ICP should become a permanent element of the global statistical system and should be conducted more frequently (World Bank 2016).

The detailed results of the 2011 survey were published in October 2015 and this chapter is largely based on the 2011 survey and its results (World Bank 2015a). The chapter describes and discusses the methods adopted in, and the results from, the 2011 ICP construction survey; it is in four parts including this introduction. The second, within the limits of the author's information and understanding, summarizes the main elements of the approach adopted by the ICP and describes how and why work on it evolved as it did (the author acted as a consultant to the ICP on the construction survey from 2009 to 2013). The third presents and comments on selected results from the ICP 2011 survey: construction PPPs, construction Price Level Indices (PLIs) and construction expenditures. A final part draws conclusions from the survey and its results and makes suggestions for the future conduct and analysis of international construction price surveys.

\section{The approach to the ICP 2011 survey}

PPPs are spatial price indices - they measure price differences across locations - and, like other price indices, their calculation calls for an appropriate list of items, prices for these items and weights that represent the contribution of each item or group of item to the activity being measured. Three key decisions were made at an early stage of development of the ICP 2011 construction survey that helped shape the approach adopted subsequently:

- $\quad$ that the work would be based on construction resources (primarily materials and products, labour and hire of construction equipment), i.e. construction inputs rather than outputs such as construction projects

- that input prices paid by contractors to suppliers for construction resources would be collected, rather than output prices (prices paid by purchasers for completed construction work); and

- $\quad$ that the aim would be to produce PPPs for different types of construction work and for all construction work directly rather than via construction projects.

The rationales for these decisions emerge in the text that follows. 
The broad approach adopted for the ICP 2011 construction survey and how that evolved over the period 2009 to 2013 is described below. It comments on the selection of items, the collection of prices and the choice of weights (for reviews of alternative and previous ICP methods for construction surveys see Chapter 4 in Best and Meikle 2015). This chapter does not cover the period of final production of PPPs.

\section{Selection of items}

The items included in the construction price survey were selected as being representative of most types of construction work, relatively straightforward to describe and in common use across most countries. A total of fifty items was selected - enough to give a reasonable spread and not so many as to make collecting prices too burdensome for respondents - 38 materials and products, seven types of labour and five types of construction equipment (machinery such as excavators, cranes, etc used during construction works). Best undertook a survey of published price data that informed the selection of items (for a summary of that work see the Appendix to Chapter 4 in Best and Meikle 2015). Some effort was also made to link items in the ICP 2005 and 2011 construction price surveys. The selected items and their brief descriptions are listed in the appendix to this chapter. Additional notes and images for materials and products and equipment were prepared by the World Bank Global Office and provided to survey respondents.

The survey form permitted respondents to price alternatives where items specified in the survey documents were not commonly available but local equivalents were, for example, common sand and cement bricks could replace common clay bricks; commonly used hardwoods could replace softwood, and so on. Preferred units were provided for all items, for example, $\mathrm{m}^{3}$ for sand and aggregates, $\mathrm{m}^{2}$ for plywood, days for bricklayers, but provision was also made for respondents to insert other units in common use locally. This involved those checking and analyzing survey responses to convert prices for items based on local units to prices for standard units. Experience from the 2011 survey indicates that the survey instrument, including the selection of items, item descriptions and supporting notes could all be improved but that the general approach was broadly satisfactory. The Appendix also indicates, with coefficients of variation (CoVs), which items were more variable in their pricing than others; the CoVs and their significance are discussed in more detail below.

\section{Collection of prices}

ICP-type exercises call for the comparison of prices of comparable products or services in each country; ideally these items should be as close to identical as possible. Most consumption price data is based on multiple observations of retail prices paid directly by end 
users for more or less identical products or services - packets of cornflakes, tubes of toothpaste, haircuts, for example. With few exceptions, this is not possible for construction; comparable, never mind identical, construction projects are difficult, if not impossible, to find.

It is difficult to observe any construction prices, but reliable output prices are particularly problematic as they are only available for completed projects and these will always incorporate context, locational, temporal, site and project dependent factors that can significantly impact on price levels and comparability. Examples include climatic and seismic conditions, market factors, site access, and ground conditions. In addition, projects will always be designed and built to comply with local standards, regulations and practices and prices will reflect that. And, finally, comparable units of measurement do not exist for many construction types. The majority of construction projects are more or less one-offs and, while they may well be representative of their country or location of origin, they are not strictly comparable across countries.

Reliable input prices are also difficult to collect but less so than output prices. The decision was made, therefore, to concentrate on input prices and, if possible, adjust these to approximate output prices. A major advantage is that prices for standard units of purchase $\mathrm{m}^{3}$ for concrete, $\mathrm{m}^{2}$ for plywood, days for the hire of labour, for example - are available. Published input prices such as official labour rates and material price lists, however, are indicative only and are not appropriate for many types of construction work. Large projects can attract substantial quantity discounts and large contractors can obtain discounts regardless of the size of any particular project; smaller projects and smaller contractors will often pay significantly higher prices for construction resources. Collecting representative input prices, therefore, calls for care and experience.

Provision was made in the survey form for adjustments for some or all of the regional variations (where other than national average prices were provided), contractors' mark-ups (for site and head office overheads and profit) and professional fees. Data for mark-ups and professional fees was collected but not used due to data gaps and concerns about data quality. The approach followed for filling gaps in price data is explained in detail in Chapter 19 of the ICP Operational Guidelines (World Bank 2015d).

National construction experts were selected as the primary sources of price data, i.e. government employees, industry researchers or private consultants. This generally meant that only single price observations were reported in each country. However, national experts, if chosen sensibly, bring broad experience of different types of construction in different 
locations and circumstances. All other construction PPP methodologies use national construction experts, although usually for output and/ or project prices. External experts take time to identify, appoint and brief, and require payment. The ICP 2011 timetable was very condensed and survey preparation and validation may have benefited from additional time.

The ICP calls for annual average and national average prices although mid-year prices were accepted instead of annual averages. National averages (i.e. an average of prices charged throughout a country) are asked for in the ICP survey although sometimes prices were provided for specific locations - usually, capital or main cities. Where this was done, respondents were also asked for a factor to convert prices submitted to national average prices. More time spent training respondents should improve response rates and the quality of responses.

The survey form was designed so that different 'baskets' of materials could be compiled for each of three types of construction work - residential and non-residential building and civil engineering. These baskets are termed by the World Bank as basic headings, components of the economy for which PPPs are calculated, however only one construction PPP is published, for 'All construction', an expenditure weighted aggregate of the three basic heading construction PPPs. For example, cement and steel are commonly used in all types of construction, roof tiles are used in building work and not in civil engineering. Respondents were asked to select items that were considered locally 'important' for each type of work/ basic heading. Importance was defined as items that were readily available and commonly used. The Global Office established default selections for those countries that could or did not (see Appendix).

'All-in' prices were also collected for different types of construction work, for example, per $\mathrm{m}^{2}$ for buildings or per metre run for drains. Although this method of estimating project prices is commonly used in many countries, the results are not very reliable as there are different inclusions and exclusions, different rules of measurement and the prices provided are for projects representative of each country which are not necessarily comparable across countries. Not all respondents completed this section of the survey and the data collected was not used.

Checking and validation of the construction survey data was generally undertaken by large groups of national statisticians that reviewed a range of survey results across all elements of GDP. This author's personal experience from the Eurostat construction price surveys suggests that smaller groups involving construction experts are useful to help resolve misunderstandings and arrive at acceptable price data. 
It is difficult to independently and reliably assess the extent to which item prices or price levels vary from 'correct' values, not least because objectively correct values are not known. But variability in construction prices can be very high. A study for the World Bank indicated that, within a country, project estimates can vary by $\pm 10 \%$, trade estimates within a project can vary by up to $25 \%$, and individual items can vary by at least $50 \%$ (Sinclair et al. 2002). Variability across countries can be much higher. An exercise by Davis Langdon for Eurostat indicated that, across the members of the European Union in 2009, project prices (normalized by PPPs) varied by almost $100 \%$, work group (trade or element) prices varied by more than 150\% and individual items varied by factors of six to 20 (Davis Langdon, n.d.). Submitted prices, therefore, should not be rejected or amended merely because they are subjectively considered to be ‘too high’ or 'too low'. Apparent outliers should be thoroughly checked with respondents to ensure that they relate to the particular item, that the items are in common use and that the correct units have been priced. Wherever possible, triangulation should be used to cross check data and results from different sources and methods.

An analysis was undertaken of the variability, indicated by coefficients of variation (CoV), of individual price levels from a group of around 100 countries (Thomas 2013). A similar approach was used by Best (2008) in analyzing input costs from six locations. The CoVs for all resources are included in the Appendix and commented on below.

The CoV of each item measures how closely the price level of that item is to all the national price levels for that group of items. An item with a low CoV is a better proxy for national price levels than one with a high $\mathrm{CoV}$. Item CoVs are calculated from item price levels (after conversion to a common currency) divided by overall country price levels for each group of items. Separate CoVs are calculated for materials and products, and labour and equipment items. Table 9.1 presents the materials and products with the highest CoVs and those with the lowest; it also shows low, high and average CoVs for labour and equipment items.

\begin{tabular}{|l|l|l|l|l|l|}
\hline Materials and products & \multicolumn{2}{l|}{ Labour and equipment items } \\
\hline Items with highest CoVs & $\mathbf{C o V}$ & Items with lowest CoVs & CoV & Selected items & CoV \\
\hline Sheet glass & 2.80 & Ready mix concrete & 0.64 & Carpenter & 0.11 \\
\hline Electricity & 2.21 & Structural steel & 0.63 & Electrician & 0.19 \\
\hline Wash hand basin & 1.88 & Aggregate & 0.59 & Machine operator & 0.36 \\
\hline Electric fan & 1.60 & Sand & 0.56 & Average labour CoV & 0.19 \\
\hline Cast iron pipe & 1.58 & High yield rebar & 0.54 & Tandem vibrating roller & 0.26 \\
\hline AC equipment & 1.49 & Mild steel rebar & 0.52 & Skid steer loader & 0.31 \\
\hline Electric pump & 1.41 & Portland cement & 0.52 & Tracked tractor & 0.35 \\
\hline Average materials CoV & 1.07 & Precast concrete slabs & 0.51 & Average equipment CoV & 0.28 \\
\hline
\end{tabular}

Table 9.1 Coefficients of variation for selected items (based on Thomas 2013) 
The materials and products overall indicate the greatest variation compared with labour and equipment items, even those with the lowest CoV. The labour items, with the exception of the machine operator, indicate the lowest CoVs and the equipment items are in between. The relatively low CoVs for both the labour and equipment items are not because their prices are more consistent across countries (they are not) but because they tend to be more consistent within countries.

The items with higher CoVs for materials and products are a mixture of complex manufactured and internationally traded items and electricity, influenced by exchange rates, transport costs and government policies; the lower $\mathrm{CoV}$ materials and products are commodity items, either locally produced or internationally traded. The lower CoV items are also generally those that are easier to specify while at least some of the higher CoV items are more difficult to specify and/or more likely to be produced to local requirements.

It is difficult to conclude too much from this analysis other than that the simpler and easier to describe an item is, the more likely that its price level will be relatively consistent with other price levels in that item group in that country; and the more complex and country-specific an item is, the more likely it is to have different price levels. But the incidence of different price levels for construction items within a country is not unusual. Analysis like this is undertaken on Eurostat results as part of the validation exercise and can help identify possible outliers, but outliers are not necessarily wrong, they just require thorough checking.

The author's experience of a limited number of ICP 2011 validation meetings and reviews suggests that mechanical and electrical items (pumps, fans, air conditioning equipment and the like) and roofing materials (tiles and sheet) are problematic. Their specifications often tend to be country-specific and may require some adjustment to make them comparable. If possible, item descriptions should be improved, and in the most extreme cases the items should probably be omitted. There is also doubt whether petrol and diesel fuel and electricity should be included; they are probably not that significant as construction resources and their prices can be heavily influenced by national taxes or subsidies. Interestingly, some, but not all, of these items also have higher CoVs.

\section{Choice of weights}

During the preparations for the ICP 2011 survey, a number of methods were considered for weighting resources to represent different types of construction work (basic headings). The main ones considered - and rejected - were weights based on the mix of inputs in the 
construction column or columns of national Input-output or Supply and use tables and weights derived from model projects.

Input-output/ Supply and use table-based weights were rejected because not all countries had these kinds of presentations of national accounts and many of them were not considered sufficiently consistent in form and content, or sufficiently reliable or up-to-date. In addition, many national tables only have a single column for construction, although some have multiple columns, eg. for residential buildings, civil engineering work, etc. Tables with single columns for construction work can only be used to produce 'all construction PPPs'. This problem is reducing and will almost certainly continue to reduce over time. A recent African Development Bank (AfDB) survey, reported in the African Statistical Journal, indicated that 29 African countries have compiled at least one table since 2000 and 14 countries now compile them every year (AfDB 2014). The Asian Development Bank (ADB) has been assisting member countries in the production of tables for some time and 17 Asian countries now compile them (ADB 2012). The OECD publishes standardized Input-output tables on an annual basis for 61 OECD and non-OECD countries (OECD 2018). The inputoutput based approach deserves further study, at least as a check on PPPs at the 'all construction’ level.

Project based weights were rejected because it was felt that coming up with a set of projects that would reasonably represent construction work and provide acceptable comparisons across the range of countries in the ICP was too difficult. And, in any case, 'projects' in these types of exercises are typically newbuild projects; it is extremely difficult to identify, describe and price refurbishment or conversion projects and these can comprise a significant proportion of construction expenditure in many countries. There is also the problem of aggregating projects to types of work.

The method finally adopted for combining individual groups of resources (materials, labour and equipment) was, broadly, to calculate price relatives (effectively PPPs) for each resource item and then aggregate individual groups of resource items using geometric means.

Aggregate resource PPPs were then combined into basic heading PPPs using the estimated shares (resource mixes) that each resource represents in each basic heading's output. Details of calculation methods are set out in the ICP Operational Guidelines (World Bank 2015d).

Resource mixes were generally provided by national experts although the ICP Global Office also developed a set of default values that were used when respondents could not or did not provide their own national resource mixes. The rationale behind the resource mix approach is that materials represent the final product of construction activity and are common - that is, 
comparable - across countries. The labour and equipment inputs, on the other hand, are only used during construction works and the proportions of these in resource mixes represent local practice, technology, productivity and other factors. The key is that volume measures of materials are directly comparable across countries whereas labour and equipment are country specific and their volume or value depends on how construction is carried out in each country.

The research base for resource mixes is limited; an initial ICP note cited only around ten sources of data (Meikle 2011a). The initial estimates were, therefore, prepared on the basis of rather limited data although they were subsequently adjusted in the light of mixes received from countries during the ICP construction survey (Meikle 2013). Country responses, like the main survey price data, mostly came from single observers, although, as noted previously, such observers bring broad experience to the exercise. Table 9.2 sets out both the initial and subsequently revised 'default' sets of resource mixes. The second set is based on responses from around 100 countries.

\begin{tabular}{|c|c|c|c|c|c|c|c|c|c|}
\hline \multirow[b]{2}{*}{ Groups of countries } & \multicolumn{3}{|c|}{ Residential } & \multicolumn{3}{|c|}{ Non-residential } & \multicolumn{3}{|c|}{ Civil engineering } \\
\hline & Mat. & Equip. & Lab. & Mat. & Equip. & Lab. & Mat. & Equip. & Lab. \\
\hline \multicolumn{10}{|c|}{ Initial Global Office averages } \\
\hline Low income countries & 72.50 & 7.50 & 20.00 & 72.50 & 10.00 & 17.50 & 50.00 & 35.00 & 15.00 \\
\hline Middle income countries & 72.50 & 5.00 & 22.50 & 70.00 & 7.50 & 22.50 & 50.00 & 28.75 & 21.25 \\
\hline High income countries & 70.00 & 5.00 & 25.00 & 66.67 & 7.50 & 25.83 & 50.00 & 25.00 & 25.00 \\
\hline \multicolumn{10}{|l|}{ Revised default mixes } \\
\hline Low income countries & 62.50 & 15.00 & 22.50 & 62.50 & 17.50 & 20.00 & \multirow{3}{*}{\multicolumn{3}{|c|}{ No change }} \\
\hline Middle income countries & 60.00 & 12.50 & 27.50 & 60.00 & 15.00 & 25.00 & & & \\
\hline High income countries & 57.50 & 10.00 & 32.50 & 57.50 & 12.50 & 30.00 & & & \\
\hline
\end{tabular}

Table 9.2 Initial resource mixes and possible adjusted mixes (Meikle 2011a, 2013)

The major differences between the initial and the revised default mixes for residential and non-residential building work are a significant increase in equipment percentages of around $100 \%$, a smaller (10-20\%) increase in labour percentages and a $10-15 \%$ decrease in material percentages. Civil engineering mixes are much more variable than building mixes, but the initial averages were broadly similar. Overall there was broad agreement among countries on resource mixes, but more work is needed on this aspect.

Other weights, from basic heading PPPs to ‘all construction’ PPPs, are more straightforward; simple expenditure value weights, provided by countries, were used. In summary, aggregate price relatives were used to obtain resource PPPs, resource mixes are used to obtain type of work (basic heading) PPPs and expenditure weights are used to obtain 'all construction' PPPs. 
As indicated in Fig. 9.1, the resource approach to the calculation of PPPs adopted in ICP 2011 generates 13 separate PPPs: labour, material, equipment and aggregate PPPs for residential, non-residential and civil engineering construction as well as the aggregate 'all construction’ PPP

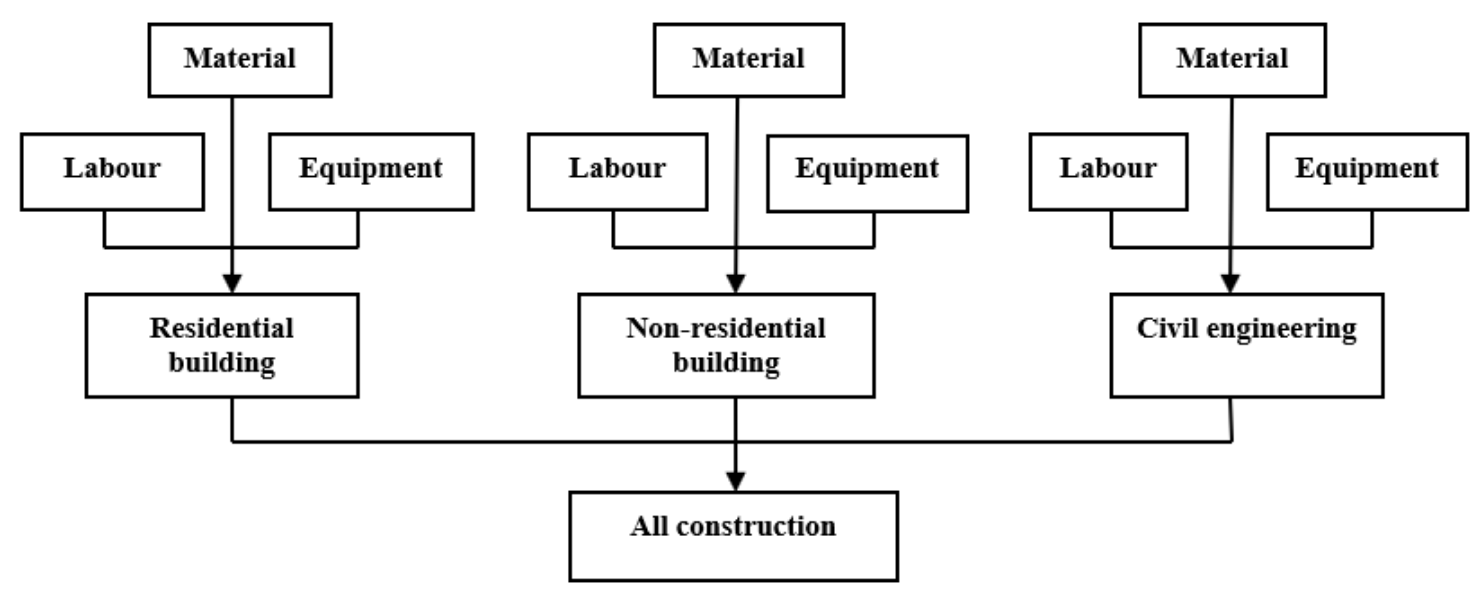

Fig. 9.1 Construction PPPs for resources, basic headings and all construction

Only one, the 'all construction' PPP, is published for each country but basic heading level PPPs are available to researchers through the ICP 2011 data access policy (World Bank 2012). Detailed study of all 13 PPPs might allow researchers to identify the main drivers of 'all construction' price levels: is it labour or materials, is it residential or civil engineering construction, or is it some other combination? It might also be possible to comment on other issues including, for example, productivity levels.

\section{The ICP construction results}

In addition to a detailed description and discussion of the survey, the published ICP results (World Bank 2015a) provide a detailed set of tables that include almost 200 countries. The main tables are:

- $\quad$ GDP PPPs and PPPs for selected economic categories;

- $\quad$ Price Level Indices (PLIs) for GDP and selected categories; and

- $\quad$ GDP and basic heading expenditures in national currencies, in \$US using exchange rates and in \$US based on PPPs.

The ICP values for construction PPPs are based on three calculation methods: the Eurostat/ OECD method used by 47 countries across Europe, North and South America, Asia and Oceania; the method used by nine Confederation of Independent States (CIS); and the ICP 2011 method used by the remaining 120 or so countries; for descriptions of the Eurostat/ OECD and CIS methods, see Chapter 5 in Best and Meikle (2015). 
The main purpose of the ICP is, of course, to produce GDP and sub-GDP PPPs. The ICP also presents expenditure data in national currencies and in USD using exchange rates and PPPs. PLIs are derived directly from PPPs, by dividing PPPs by exchange rates, and are expressed as indices with the World equal to 100. The expenditure data in national currencies is provided by national statistical offices. The ICP Results include 13 categories of consumption (from food and drink and clothing through housing and transport to health and education) and the two main categories of investment, machinery and equipment (M\&E) and construction.

Where possible, this chapter uses normalized data and a sample of countries. PLIs are normalized (comparable) representations of PPPs; expenditure data is normalized by dividing by national populations and expressed as expenditures per capita or as percentages of GDP. The sample of countries is used to illustrate and comment on the results; the main rationales for their selection are that the countries cover the main ICP regions or groups, that they are significant in terms of population and economic size in their region, and that they exclude countries where PPPs have been calculated using the Eurostat/ OECD or CIS calculation methods. The countries selected are listed in Table 9.3. The ICP regions and groups of countries are Africa [50 countries], Asia and the Pacific [23], Commonwealth of Independent States [9], Latin America and the Caribbean [39], OECD - Eurostat [47], Pacific Islands [23], Singleton Countries [2], Western Asia [12], Dual Participation (countries included in more than one region) [6].

\section{Purchasing Power Parities (PPPs)}

The construction PPPs presented in the ICP results are annual and national average expenditure weighted aggregates of residential, non-residential and civil engineering PPPs calculated from the ICP construction price surveys. They are not linked to any particular type of construction project or any particular location. ICP PPPs are transitive, i.e. like exchange rates, they can be rebased to any country and the relative relationships will remain constant. Table 9.3 presents population and World Bank income group data and exchange rates, GDP PPPs and investment PPPs for a range of countries relative to one USD.

With the exception of Hungary and Saudi Arabia, the richer upper income countries have GDP PPPs at the same or slightly higher levels than their exchange rates; Hungary's and Saudi Arabia's GDP PPPs are markedly lower, probably because of relatively low costs of labour. The upper-middle and lower-middle income countries all have GDP PPPs lower than their exchange rates. The different investment PPPs indicate more clearly the influence of PPPs on different components of economies. Machinery and equipment PPPs, representing 
internationally traded items, are often (unsurprisingly) close to exchange rates in most countries; construction PPPs, on the other hand, are much lower than exchange rates or GDP PPPs in poorer countries, reflecting the essentially local nature of construction. This indicates that construction expenditure and construction volumes tend to be understated, sometimes significantly so, in poorer countries.

\begin{tabular}{|c|c|c|c|c|c|c|c|c|}
\hline \multirow[b]{2}{*}{ Country } & \multirow[b]{2}{*}{ Region $^{+}$} & \multirow[b]{2}{*}{$\begin{array}{c}\text { Population } \\
\text { (millions) }\end{array}$} & \multirow[b]{2}{*}{$\begin{array}{c}\text { GDP per } \\
\text { capita } \\
\text { USD PPP }\end{array}$} & \multirow[b]{2}{*}{$\begin{array}{l}\text { Income } \\
\text { Group* }\end{array}$} & \multirow[b]{2}{*}{$\begin{array}{c}\text { Exchange } \\
\text { rate to } \\
\text { USD }\end{array}$} & \multirow[b]{2}{*}{$\begin{array}{l}\text { GDP PPP } \\
\text { (base USD } \\
=1.00 \text { ) }\end{array}$} & \multicolumn{2}{|c|}{ Investment PPPs } \\
\hline & & & & & & & Construction & $\begin{array}{l}\text { Machinery } \\
\text { and } \\
\text { equipment }\end{array}$ \\
\hline Brazil & LAC & 192.38 & 14,639 & UM & 1.673 & 1.471 & 0.722 & 2.823 \\
\hline China & Asia & $1,341.98$ & 10,057 & $\mathrm{UM}$ & 6.461 & 3.506 & 2.184 & 7.771 \\
\hline Colombia & LAC & 47.09 & 11,360 & UM & $1,848.139$ & $1,161.910$ & 883.72 & $2,528.15$ \\
\hline Costa Rica & LAC & 4.59 & 13,030 & UM & 505.664 & 346.738 & 233.246 & 798.305 \\
\hline Hungary & E/OECD & 9.97 & 22,413 & $\mathrm{H}$ & 200.966 & 123.650 & 102.368 & 209.985 \\
\hline India & Asia & $1,215.96$ & 4,735 & LM & 46.670 & 15.109 & 9.598 & 48.134 \\
\hline Indonesia & Asia & 241.04 & 8,539 & LM & $8,770.433$ & $3,606.566$ & $1,920.377$ & $9,087.622$ \\
\hline Netherlands & E/OECD & 16.69 & 43,150 & $\mathrm{H}$ & 0.719 & 0.832 & 0.690 & 0.920 \\
\hline $\begin{array}{l}\text { Saudi } \\
\text { Arabia }\end{array}$ & WA & 28.38 & 48,163 & $\mathrm{H}$ & 3.750 & 1.837 & 0.876 & 3.279 \\
\hline $\begin{array}{l}\text { South } \\
\text { Africa }\end{array}$ & Africa & 50.46 & 12,111 & UM & 7.261 & 4.774 & 2.782 & 9.138 \\
\hline Tunisia & Africa & 10.59 & 10,319 & UM & 1.408 & 0.592 & 0.253 & 1.913 \\
\hline UK & E/OECD & 62.74 & 35,091 & $\mathrm{H}$ & 0.624 & 0.698 & 0.546 & 0.668 \\
\hline USA & E/OECD & 312.04 & 49,782 & $\mathrm{H}$ & 1.000 & 1.000 & 1.000 & 1.000 \\
\hline
\end{tabular}

Table 9.3 Selected countries, key indicators (World Bank 2012)

* World Bank income groups, 2011: $\mathrm{H}$ = high income (>USD PPP 12,276); UM = upper-middle income (USD PPP

3,976 - 12,275); LM = Lower-middle income (USD PPP 1,006 - 3,975).

${ }^{+}$LAC = Latin America and the Caribbean; E/OECD = Eurostat/ OECD; WA = Western Asia

\section{Price Level Indices (PLIs)}

Price Level Indices (PLIs) are calculated by dividing PPPs by exchange rates. GDP, all economy, PLIs are calculated by dividing GDP PPPs by exchange rates; PLIs for parts of the economy are calculated by dividing, for example, construction, and machinery and equipment PPPs by exchange rates. Although PPPs are calculated for each component of GDP, there is only one commercial exchange rate; in the same way, there are PLIs for each component of GDP.

It may seem odd to bring exchange rates back into the discussion. The purpose of PLIs, however, is to allow price levels for different parts of the economy and whole economies to be compared across a range of countries. Just as exchange rates relate to a particular point in time, so do PPPs, so calculating the relationship between exchange rates and PPPs at that 
point in time is both valid and useful as PLIs can be directly compared where PPPs cannot. PLIs normalize PPPs and make them comparable. The PLIs published in the ICP 2011

Results are presented as factors with the World equivalent to 100 and, like PPPs, PLIs are transitive (they can be rebased to any country and the relationships between countries stay the same).

Table 9.4 includes the same countries as Table 9.3 and presents PLIs for the whole economy, construction, and machinery and equipment.

\begin{tabular}{|l|r|r|r|r|r|}
\hline Country & GDP PPPs & \multicolumn{1}{c|}{$\begin{array}{c}\text { Exchange } \\
\text { rates }\end{array}$} & GDP PLIs & $\begin{array}{c}\text { Construction } \\
\text { PLIs }\end{array}$ & \multicolumn{1}{c|}{ PLIs E } \\
\hline Brazil & 1.36 & 2.43 & 113.4 & 88.0 & 144.3 \\
\hline China & 3.45 & 8.19 & 70.0 & 68.9 & 102.8 \\
\hline Colombia & 1081.95 & 2320.75 & 81.1 & 97.5 & 117.0 \\
\hline Hungary & 128.51 & 199.47 & 79.3 & 103.8 & 89.3 \\
\hline India & 14.67 & 44.10 & 41.7 & 41.9 & 88.2 \\
\hline Indonesia & 3934.26 & 9704.74 & 53.0 & 44.6 & 88.6 \\
\hline Netherlands & 0.90 & 0.80 & 149.1 & 195.5 & 109.4 \\
\hline Saudi Arabia & 2.41 & 3.75 & 63.2 & 47.6 & 74.8 \\
\hline South Africa & 3.87 & 6.36 & 84.8 & 78.1 & 107.6 \\
\hline Tunisia & 0.58 & 1.30 & 54.2 & 36.6 & 116.2 \\
\hline UK & 0.65 & 0.55 & 144.2 & 178.2 & 91.5 \\
\hline USA & 1.00 & 1.00 & 129.0 & 203.9 & 85.5 \\
\hline
\end{tabular}

Table 9.4 Selected countries, PPPs (USD=1.00) and price level indices (world=100)

Source: ICP 2011 results (World Bank 2015a)

Table 9.4 illustrates the value of PLIs; they can be compared directly in the table, unlike exchange rates or PPPs. For example, Brazil's GDP PLI (its general price level) is higher than Colombia's but lower than the USA's; its construction PLI is lower than Colombia's and much lower than the USA's. The table clearly shows that the range of machinery and equipment PLIs (85.5 - 144.3, 1.7:1) is much narrower than either GDP (41.7 - 149.1, 3.6:1) or, particularly, construction PLIs (41.9 - 203.9, 4.9:1). This supports the idea that price levels across countries for internationally traded items will tend to be closer to each other than those for more local items.

\section{Construction expenditure data}

In the ICP, construction expenditure data is provided to the ICP Global Office in national currencies by national statistical offices. It is - or should be - the gross value of construction output in each country's national accounts, that is, it should include all construction activity in the economy. It should, therefore, include all capital construction work (new work and major renovations or extensions) by construction contractors, by households and by others 
where their activity is registered to construction. There is evidence, however, that this is not necessarily the case or, at least, that what is included or excluded is not consistent across countries. Possible exclusions are discussed below.

Other chapters in this volume discuss the problems of measuring construction output data in the UK, (see Chapter 4) and informal or shadow construction activity in Australia and New Zealand (see Chapter 5). These or similar problems occur in all countries and create issues of both measurement and comparability. According to a report by AT Kearney, in five major European economies (Germany, Italy, Poland, Spain and Turkey), construction has the most prevalent shadow economy of any sector, making up at least $30 \%$ of all work in that sector (AT Kearney 2013). It should be noted that the Kearney figures are based on modelled data, not survey data.

It should also be noted that ICP construction PPPs include professional fees although these are not - or not all, or always - included as construction output in many countries (e.g. in the UK, construction professional services are excluded from construction output data and included in the UK national accounts as professional services).

A recent survey of national statistical offices in Africa illustrates the variability in what is included in, or excluded from, construction in the national accounts of a sample of countries (Meikle 2011b). Table 9.5 sets out the range of inclusions and exclusions and the data collection methods.

\begin{tabular}{|l|l|l|l|}
\hline \multirow{2}{*}{ Countries } & Construction activity & By households \\
\cline { 2 - 4 } & By registered contractors & $\begin{array}{l}\text { By unregistered } \\
\text { contractors }\end{array}$ & Excluded \\
\hline Botswana & $\begin{array}{l}\text { Based on survey; very small work } \\
\text { excluded }\end{array}$ & Excluded \\
\hline Ethiopia & $\begin{array}{l}\text { Based on survey and estimates; } \\
\text { very small work excluded }\end{array}$ & $\begin{array}{l}\text { Based on survey and } \\
\text { estimates }\end{array}$ & Based on survey and estimates \\
\hline Malawi & Based on survey and estimates & Excluded & Estimated \\
\hline Mauritius & Based on survey & Estimated & Estimated \\
\hline South Africa & Based on survey & Based on survey & Based on survey \\
\hline Swaziland & Based on survey & $\begin{array}{l}\text { Based on survey and } \\
\text { estimates }\end{array}$ & $\begin{array}{l}\text { Urban buildings using modern materials } \\
\text { included; otherwise excluded }\end{array}$ \\
\hline Uganda & $\begin{array}{l}\text { Estimated; repair and } \\
\text { maintenance and very small work } \\
\text { excluded }\end{array}$ & Estimated & Estimated \\
\hline
\end{tabular}

Table 9.5 Construction in the national accounts of selected African countries (Meikle 2011b)

The table demonstrates that the comparability of country construction data is questionable in a number of cases. More detailed information from countries collected at the same time as the survey indicates that historic survey data or estimates are updated using population or household growth, rates of urbanization or consumption of construction materials, 
particularly cement, or some combination of these. Regular dedicated construction activity surveys are rare in Africa.

Table 9.6 sets out GDP per capita and construction expenditure per capita data from the ICP 2011 Results for the same set of countries, all in USD, using exchange rates and PPPs. Two methods have been used to aggregate individual country expenditures: Geary-Khamis (GK) and Gini-Elteto-Koves-Szulc (GEKS).

\begin{tabular}{|c|c|c|c|c|c|c|c|c|c|}
\hline \multirow{3}{*}{ Country } & \multicolumn{3}{|c|}{$\begin{array}{l}\text { Nominal expenditure in } \\
\text { USD bn using exchange } \\
\text { rates }\end{array}$} & \multicolumn{3}{|c|}{$\begin{array}{l}\text { Real expenditure in USD bn } \\
\text { using PPPs and GEKS } \\
\text { weights }\end{array}$} & \multicolumn{3}{|c|}{$\begin{array}{l}\text { Real expenditure in USD bn } \\
\text { using PPPs and GK weights }\end{array}$} \\
\hline & \multirow[b]{2}{*}{ GDP } & \multicolumn{2}{|c|}{ Construction } & \multirow[b]{2}{*}{ GDP } & \multicolumn{2}{|c|}{ Construction } & \multirow[b]{2}{*}{ GDP } & \multicolumn{2}{|c|}{ Construction } \\
\hline & & Amount & $\%$ & & Amount & $\%$ & & Amount & $\%$ \\
\hline Brazil & $2,476.6$ & 197.7 & 8.0 & $2,818.3$ & 458.2 & 16.3 & $1,380.1$ & 166.2 & 12.0 \\
\hline China & $7,321.9$ & $2,106.3$ & 28.8 & $13,495.9$ & $6,230.3$ & 46.2 & $7,514.8$ & $2,474.6$ & 32.9 \\
\hline Colombia & 336.3 & 48.9 & 14.5 & 535.0 & 102.2 & 19.1 & 266.0 & 35.2 & 13.2 \\
\hline Costa Rica & 41.0 & 4.4 & 10.7 & 50.8 & 9.5 & 18.7 & 29.4 & 3.6 & 12.2 \\
\hline Hungary & 137.5 & 12.8 & 9.3 & 233.5 & 25.2 & 10.8 & 122.9 & 10.2 & 8.3 \\
\hline India & $1,864.0$ & 334.7 & 18.0 & $5,757.5$ & $1,627.2$ & 28.3 & $3,293.9$ & 665.4 & 20.2 \\
\hline Indonesia & 846.3 & 219.3 & 25.9 & $2,058.1$ & $1,001.7$ & 48.7 & $1,234.2$ & 393.7 & 31.9 \\
\hline Netherlands & 832.8 & 84.0 & 10.1 & 720.3 & 87.6 & 12.2 & 426.2 & 35.2 & 8.3 \\
\hline $\begin{array}{l}\text { Saudi } \\
\text { Arabia }\end{array}$ & 669.5 & 75.2 & 11.2 & $1,366.7$ & 322.0 & 23.6 & 774.6 & 129.1 & 16.7 \\
\hline South Africa & 401.8 & 36.5 & 9.1 & 611.1 & 95.3 & 15.6 & 253.7 & 29.4 & 11.6 \\
\hline Tunisia & 46.0 & 6.3 & 13.7 & 109.3 & 35.2 & 32.2 & 62.6 & 13.8 & 22.0 \\
\hline UK & $2,461.8$ & 202.3 & 8.2 & $2,201.4$ & 231.4 & 10.5 & $1,175.8$ & 95.1 & 8.1 \\
\hline USA & $15,533.8$ & $1,295.0$ & 8.3 & $15,533.8$ & $1,295.0$ & 8.3 & $8,215.4$ & 529.2 & 6.4 \\
\hline
\end{tabular}

Table 9.6 Nominal and real GDP and construction expenditure data in USD

Source: ICP 2011 results (World Bank 2015a) and World Bank experimental data (unpublished)

Detailed descriptions of the methods can be found in the Comprehensive Report of the 2011 International Comparison Program (World Bank, 2015b:255-256). In brief, the GEKS method is considered by many statisticians as superior but, as a result of using it, the components of GDP are not additive; it was used for the 2011 published ICP data. The GK data is additive and was used for ICP results up until the 1980s but is now considered statistically inferior for producing values for both GDP and the components of GDP Ádditive means that the components components of GDP, including construction expenditure, sum to the total of GDP. The fact that the GEKS based data does not allow the components of GDP to be summed to GDP means that the relationships between the components and between the components and GDP are not necessarily reliable. Experimental data using the GK method was provided to the author by the World Bank Global Office. 
The GEKS data generally looks to be in line with expectations, i.e. generally, values increase in poorer countries and reduce in richer countries and the increases and decreases in construction expenditure are generally greater than those in GDP. The GK data, on the other hand, is less predictable with only Chinese, Indian, Saudi Arabian and Tunisian real values greater than their nominal values and Dutch, Hungarian, UK and US real values significantly lower.

The expenditure data in the ICP Results presents at least two problems for construction analysts. Firstly, the basic data provided by national statistical offices may not represent the same concepts; and secondly, the non-additivity of the published data in PPPs does not, for example, allow credible figures for construction expenditure as a proportion of GDP (or GFCF) to be calculated.

\section{Summary and conclusions}

A first and important conclusion is that, although the ICP results may not be absolutely reliable, they are much better than anything else available. The more reliable figures in the ICP Results are probably the GDP and GDP PPPs data and some of the less reliable are data on the components of GDP, including the construction expenditure data. Greater awareness about the ICP and greater involvement in its work by all, including the construction industry and construction researchers, will help encourage and direct that improvement. Recent initiatives by the ICP suggest that a number of recommendations made below are being addressed by the Global Office (World Bank 2018b).

There are shortcomings in the ICP 2011 documentation and approach and these will have influenced survey outcomes. There is uncertainty in item selection, price collection and weights, all of which can impact on the quality of the results and, in combination, may compound any individual inaccuracies. The approach, however, is not fundamentally flawed; international construction price comparisons are just very difficult, and the difficulties should not be underestimated.

The survey documentation needs improvement and more training of respondents and more checking and validation of survey data is required. Almost certainly, too much time was spent in the run-up to ICP 2011 on construction PPP theory and methodology and not enough on practical processes and data quality. The following aspects of the construction survey deserve attention:

- The list of items and item descriptions and supporting information should be reviewed and revised where necessary. Changes could usefully be made to the choice of items and supporting documentation; to the treatment of alternative 
materials and products; and to the identification and adjustment of item units. As a first step, initial reviews of the survey should be revisited and updated (see, for example, Meikle and Thomas 2013)

- The collection of data on, and the treatment of mark-ups, profits and productivity, needs to be re-examined and new approaches developed.

- More effort is needed on the selection of national construction experts and their familiarization with the purpose and content of the survey and survey documentation. There is great reliance on expert pricing and prices and enough time and effort needs to be put into informing the experts about the survey and how it should be completed.

- $\quad$ Rigorous procedures for checking and validation are needed and these need to involve national construction experts. Checking of prices and adjusting for alternative materials and alternative units provide opportunities for error and enough time needs to be allowed to ensure that adjustments are made correctly and confirmed with respondents. Construction prices are highly variable and this needs to be recognized.

- Benchmark prices, i.e. prices from non-survey sources, were introduced in the 2011 survey as checks on, not alternatives to, respondents’ prices. More work could be done on this, for example, using official national average construction earnings data or commodity price data. A recent survey by Chinganye and others indicated that a significant proportion of countries regularly collect price data on construction materials (around 50\%) and labour (around 25\%) (AfDB 2015).

- Research is needed on resource mixes. The ICP 2011 data is almost certainly the largest international exercise in collection of construction resource data to date. More work is required to test the reliability of this data.

It is important that the data collected in the construction survey is the best possible within realistic time and cost constraints. Good quality data is essential, regardless of the PPP calculation method adopted.

The availability and reliability of input-output tables is increasing all the time. Weights for inputs to different types of construction work and all construction based on analysis of inputoutput tables should be collected and used to produce alternative PPPs as a check against PPPs produced using unweighted price relatives.

The PPPs and the PLIs in the ICP 2011 results illustrate the broad principles of PPP theory: that general price levels in poorer countries are higher than suggested by commercial 
exchange rates and that price levels for locally produced products, including construction, are also higher. The result is actual quantities or volumes of construction work in poorer countries tend to be understated using exchange rates. But PPP and PLI data for individual countries is indicative only and relative differences in price levels between countries should not be taken as precise. Aggregate PPPs for 'all construction' are weighted averages of the three basic headings and these can be distorted by PPP values for individual basic headings and by the mix of basic headings - they are not necessarily comparable across countries.

PPPs are calculated for individual resources, basic headings and all construction (thirteen in all - see Figure 1). Analysis of these PPPs can help explain price differences, and the reasons for these differences, in a way that single construction PPPs cannot. Basic heading level PPPs, including construction PPPs, are available to researchers through the ICP 2011 data access policy (World Bank 2012).

It has been noted by a number of observers that the data and approaches used to produce PPPs could also be used to produce temporal price indices. All countries have difficulty in producing reliable indices of construction price changes over time as well as construction output deflators and it seems sensible to investigate linking work on both spatial and temporal indices for construction. Again, this is a task for the construction community.

There are reservations about the reliability and comparability of construction expenditure data, particularly in less developed countries. Elsewhere in this book Chancellor et al. discuss problems with the shadow economy in construction in developed countries. It may be that shortcomings in the quality of construction expenditure data are more significant than any problems with construction PPPs. More engagement and work is needed from the construction research community on methods for the collection or estimation and analysis of data on construction activity.

In addition, the method of aggregating expenditures in PPPs in the ICP leads to amounts, e.g. for construction, that do not sum to GDP. While this may be acceptable to, and even preferred by statisticians, it produces confusing results for construction analysts that need explanation.

The ICP construction results present one of the most complete international data sets for construction research. The focus of the ICP, however, is the production of PPPs for whole economies and broad components of GDP. The calls here for more, and more detailed, information on construction PPPs cannot realistically be addressed by the ICP Global Office; 
there is a need for the construction sector, including industry and academe, to take a lead in analyzing and presenting more complete and industry-relevant data.

\section{References and further reading}

ADB (2018) Input-Output Tables (IOT) of Selected Economies in Asia and the Pacific. https://sdbs.adb.org/sdbs/jsp/ICP/IOTDownload.jsp

AfDB (2015) The Reliability of Economic Statistics in Africa, Focusing on GDP Measurement. The African Statistical Journal, 17, December, 17-49. oads/afdb/Documents/Publications/African_Statistical_Journal_Vol.17_-_01_2015.pdf https://www.afdb.org/fileadmin/uploads/afdb/Documents/Publications/African_Statistical_Jo urnal_Vol.17_-_01_2015.pdf

A.T. Kearney (2013) The Shadow Economy in Europe. https://www.atkearney.com/financialservices/article?/a/the-shadow-economy-in-europe-2013

Best, R (2008) Development and Testing of a Purchasing Power Parity Method for Comparing Construction Costs Internationally. University of Technology, Sydney: Unpublished PhD thesis. https://www.dace.nl/download/?id=14800697

Best, R. and Meikle, J. (2015), Measuring Construction: Prices, Output and Productivity. (London: Routledge).

Davis Langdon (n.d), Variability in Eurostat construction pricing. Eurostat working paper, unpublished.

Sinclair, N., Artin, P. and Mulford, S. (2002) Construction Cost Data Workbook. Conference on the International Comparison Program, World Bank. (DMS International). www.scribd.com/document/216887572/Construction-Cost-Data-Workbook

Meikle J. (2011a) Resource mixes for construction. ICP working paper, unpublished. Meikle J (2011b) Measuring construction activity in the national accounts of African countries. ICP working paper, unpublished.

Meikle, J. (2013) A second update of construction resource mixes for the ICP 2011 round. ICP working paper, unpublished.

Meikle, J. and Thomas, P. (2013) An initial commentary on the ICP survey and the construction survey form. (unpublished)

OECD (2007) Glossary of Statistical Terms. https://stats.oecd.org/glossary/about.asp 
OECD (2018) Input-output tables. OECD.Stat.

https://stats.oecd.org/Index.aspx?DataSetCode=IOTS

Sinclair, N., Artin, P. and Mulford, S. (2002) Construction Cost Data Workbook. Conference on the International Comparison Program, Washington DC, March.

https://www.scribd.com/document/216887572/Construction-Cost-Data-Workbook

Thomas, P. (2013) Variability in ICP 2011 construction pricing. ICP working paper, (unpublished).

United Nations (2007) Handbook of the International Comparison Programme: Annex II Methods of Aggregation. http://unstats.un.org/unsd/methods/icp/ipc7_htm.htm

World Bank (2012) 2011 ICP Data Access and Archiving Policy Guiding Principles and Procedures for Data Access. International Comparison Program.

http://siteresources.worldbank.org/ICPINT/Resources/2700561255977254560/121120_ICPDataAccessPrinciples\&Procedures.pdf

World Bank (2015a) Results of the 2011 International Comparison Program. (Washington: World Bank) http://siteresources.worldbank.org/ICPEXT/Resources/ICP_2011.html

World Bank (2015b) Purchasing Power Parities and the Real Size of World Economies: a Comprehensive Report of the 2011 International Comparison Program (Washington: World Bank) http://pubdocs.worldbank.org/en/711001503680105564/ICP2011-Global-Report.pdf

World Bank (2015c) Measuring the Real Size of the World Economy: The Framework, Methodology and Results of the International Comparison Program (Washington: World Bank)

World Bank (2015d) Operational Guidelines and Procedures for Measuring the Real Size of the World Economy (Washington: World Bank)

http://www.worldbank.org/en/programs/icp/brief/2011-operational-guidelines

World Bank (n.d.) Construction Material Catalogue. ICP Operational Material http://css.escwa.org.lb/ICP/1676/Construction-Doc-MaterialsCatalogue.pdf

World Bank (2016) International Comparison Program: Governance Framework (Washington DC: World Bank). http://pubdocs.worldbank.org/en/255521487200449880/ICPGB01-Doc-Governance-Framework-Final.pdf

World Bank (2018a) International Comparison Program (ICP) http://www.worldbank.org/en/programs/icp 
World Bank (2018b) Research Agenda: PPPs for Construction.

http://www.worldbank.org/en/programs/icp/brief/ra09 


\section{CHAPTER 9 APPENDIX}

\section{ICP 2011 SURVEY ITEMS: VARIABILITY IN PRICES AND IMPORTANCE}

\section{IN BASIC HEADINGS}

\begin{tabular}{|c|c|c|c|c|c|}
\hline \multirow[b]{2}{*}{ Item } & \multirow[b]{2}{*}{ Brief description } & \multirow[b]{2}{*}{$\mathrm{C}$ of $\mathrm{V}$} & \multicolumn{3}{|c|}{ Default indicators of importance } \\
\hline & & & Residential & $\begin{array}{l}\text { Non- } \\
\text { residential }\end{array}$ & $\begin{array}{c}\text { Civil } \\
\text { engineering }\end{array}$ \\
\hline \multicolumn{2}{|c|}{ Materials and products } & 1.07 & & & \\
\hline $\begin{array}{l}\text { Aggregate for } \\
\text { concrete }\end{array}$ & $\begin{array}{l}\text { Clean, hard, strong crushed stone or gravel } \\
\text { free of impurities and fine materials in sizes } \\
\text { ranging from } 9.5 \text { to } 37.5 \mathrm{~mm} \text { in diameter. }\end{array}$ & 0.59 & $\mathbf{X}$ & $\mathbf{X}$ & $\mathbf{X}$ \\
\hline $\begin{array}{l}\text { Sand for concrete } \\
\text { and mortar }\end{array}$ & Fine aggregate washed sharp sand & 0.56 & $\mathbf{X}$ & $\mathbf{X}$ & $\mathbf{X}$ \\
\hline $\begin{array}{l}\text { Softwood for } \\
\text { carpentry }\end{array}$ & $\begin{array}{l}\text { Sawn softwood sections for structural use } \\
\text { pre-treated (to national standards) eg } 50 \mathrm{~mm} \\
\text { x } 100 \mathrm{~mm}\end{array}$ & 0.69 & $\mathbf{X}$ & $\mathbf{X}$ & $\mathbf{X}$ \\
\hline $\begin{array}{l}\text { Softwood for } \\
\text { joinery }\end{array}$ & $\begin{array}{l}\text { Dressed softwood sections for finishing eg } \\
18 \mathrm{~mm} \text { x } 120 \mathrm{~mm}\end{array}$ & 0.81 & $\mathbf{X}$ & $\mathbf{X}$ & \\
\hline Exterior plywood & $\begin{array}{l}\text { Exterior quality plywood } 15.5 \mathrm{~mm} \text { thick in } \\
\text { standard sheets }\end{array}$ & 1.32 & $\mathbf{X}$ & $\mathbf{X}$ & $\mathbf{X}$ \\
\hline Interior plywood & $\begin{array}{l}\text { Interior quality plywood } 12 \mathrm{~mm} \text { thick in } \\
\text { standard sheets }\end{array}$ & 1.31 & $\mathbf{X}$ & $\mathbf{X}$ & \\
\hline Chipboard sheet & $\begin{array}{l}\text { Interior quality chipboard } 15 \mathrm{~mm} \text { thick in } \\
\text { standard sheets }\end{array}$ & 1.19 & $\mathbf{X}$ & $\mathbf{X}$ & \\
\hline Petrol/ Gasoline & Standard grade for use in motor vehicles & 0.78 & $\mathbf{X}$ & $\mathbf{X}$ & $\mathbf{X}$ \\
\hline Diesel fuel & $\begin{array}{l}\text { Diesel fuel for use in construction } \\
\text { equipment }\end{array}$ & 0.89 & $\mathbf{X}$ & $\mathbf{X}$ & $\mathbf{X}$ \\
\hline Oil paint & $\begin{array}{l}\text { Oil based paint suitable for top coat finishes } \\
\text { to timber surfaces }\end{array}$ & 0.98 & $\mathbf{X}$ & $\mathbf{X}$ & \\
\hline Emulsion paint & $\begin{array}{l}\text { Water based paint suitable for internal } \\
\text { plaster surfaces }\end{array}$ & 0.95 & $\mathbf{X}$ & $\mathbf{X}$ & \\
\hline $\begin{array}{l}\text { Ordinary Portland } \\
\text { cement }\end{array}$ & $\begin{array}{l}\text { Ordinary Portland cement in bags or bulk } \\
\text { delivery }\end{array}$ & 0.52 & $\mathbf{X}$ & $\mathbf{X}$ & $\mathbf{X}$ \\
\hline Ready mix concrete & $\begin{array}{l}\text { Typical common mix 1:2:4 } \\
\text { cement:sand:20-40mm aggregate, } \\
\text { 20N/mm2 }\end{array}$ & 0.64 & $\mathbf{X}$ & $\mathbf{X}$ & $\mathbf{X}$ \\
\hline $\begin{array}{l}\text { Precast concrete } \\
\text { slabs }\end{array}$ & $\begin{array}{l}\text { Precast concrete paving slabs } 600 \times 600 \times \\
50 \mathrm{~mm} \text { thick }\end{array}$ & 0.51 & $\mathbf{X}$ & $\mathbf{X}$ & \\
\hline Common bricks & $\begin{array}{l}\text { Ordinary clay bricks (suitable for render or } \\
\text { plaster finish) eg } 215 \mathrm{~mm} \times 100 \mathrm{~mm} \times 65 \mathrm{~mm} \\
\text { thick }\left(715 \mathrm{bricks} / \mathrm{m}^{3} \text { ) }\right.\end{array}$ & 1.03 & $\mathbf{X}$ & $\mathbf{X}$ & $\mathbf{X}$ \\
\hline Facing bricks & $\begin{array}{l}\text { Medium quality self finished clay bricks for } \\
\text { walling, eg } 215 \mathrm{~mm} \text { x } 100 \mathrm{~mm} \text { x } 65 \mathrm{~mm} \text { thick } \\
\left(715 \text { bricks } / \mathrm{m}^{3}\right)\end{array}$ & 0.78 & $\mathbf{X}$ & $\mathbf{X}$ & \\
\hline $\begin{array}{l}\text { Hollow concrete } \\
\text { blocks }\end{array}$ & $\begin{array}{l}\text { Hollow dense aggregate concrete blocks, } \\
7 \mathrm{~N} / \mathrm{mm} 2, \text { eg } 440 \mathrm{~mm} \times 215 \mathrm{~mm} \times 140 \mathrm{~mm} \\
\text { thick }\left(76 \text { bricks } / \mathrm{m}^{3}\right)\end{array}$ & 0.79 & $\mathbf{X}$ & $\mathbf{X}$ & $\mathbf{X}$ \\
\hline $\begin{array}{l}\text { Solid concrete } \\
\text { blocks }\end{array}$ & $\begin{array}{l}\text { Solid dense aggregate concrete blocks, } \\
7 \mathrm{~N} / \mathrm{mm} 2, \text { eg } 440 \mathrm{~mm} \times 215 \mathrm{~mm} \times 140 \mathrm{~mm} \\
\text { thick }\left(76 \text { bricks } / \mathrm{m}^{3}\right)\end{array}$ & 0.90 & $\mathbf{X}$ & $\mathbf{X}$ & $\mathbf{X}$ \\
\hline Clay roof tiles & $\begin{array}{l}\text { Clay plain smooth red machine-made or } \\
\text { similar tiles per m2 of roof surface area e.g. } \\
265 \mathrm{~mm} \text { x } 125 \mathrm{~mm} \text { tiles }\end{array}$ & 0.73 & $\mathbf{X}$ & & \\
\hline Concrete roof tiles & $\begin{array}{l}\text { Concrete interlocking tiles per m2 of roof } \\
\text { surface area eg } 420 \mathrm{~mm} \times 330 \mathrm{~mm} \text { tiles }\end{array}$ & 0.74 & $\mathbf{X}$ & & \\
\hline Float/ sheet glass & Standard plain glass, clear float, $4 \mathrm{~mm}$ thick & 2.80 & $\mathbf{X}$ & $\mathbf{X}$ & \\
\hline $\begin{array}{l}\text { Double glazing } \\
\text { units }\end{array}$ & $\begin{array}{l}\text { Factory made hermetically sealed, medium } \\
\text { sized units } 0.5 \text { to } 2.0 \mathrm{~m} 2 \text { with } 4 \mathrm{~mm} \text { glass, } \\
12 \mathrm{~mm} \text { seal }\end{array}$ & 0.92 & $\mathbf{X}$ & $\mathbf{X}$ & \\
\hline Ceramic wall tiles & $\begin{array}{l}152 \times 152 \times 5.5 \mathrm{~mm} \text { thick white or light } \\
\text { coloured for medium quality domestic use }\end{array}$ & 0.83 & $\mathbf{X}$ & $\mathbf{X}$ & \\
\hline Plasterboard & $\begin{array}{l}\text { 12.5mm paper faced taper edged } \\
\text { plasterboard in standard sheets }\end{array}$ & 1.37 & $\mathbf{X}$ & $\mathbf{X}$ & \\
\hline
\end{tabular}




\begin{tabular}{|c|c|c|c|c|c|}
\hline $\begin{array}{l}\text { White wash hand } \\
\text { basin }\end{array}$ & $\begin{array}{l}\text { Average quality white vitreous china } \\
\text { domestic wash hand basin for domestic use, } \\
\text { wall hung (excluding taps, trap and } \\
\text { pipework) }\end{array}$ & 1.88 & $\mathbf{X}$ & $\mathbf{X}$ & \\
\hline $\begin{array}{l}\text { High yield steel } \\
\text { reinforcement }\end{array}$ & $\begin{array}{l}\text { Reinforcing bars up to } 16 \mathrm{~mm} \text { diameter } \\
\text { (excluding cutting and bending) }\end{array}$ & 0.54 & $\mathbf{X}$ & $\mathbf{X}$ & $\mathbf{X}$ \\
\hline $\begin{array}{l}\text { Mild steel } \\
\text { reinforcement }\end{array}$ & $\begin{array}{l}\text { Reinforcing bars up to } 16 \mathrm{~mm} \text { diameter } \\
\text { (excluding cutting and bending) }\end{array}$ & 0.52 & $\mathbf{X}$ & $\mathbf{X}$ & $\mathbf{X}$ \\
\hline $\begin{array}{l}\text { Structural steel } \\
\text { sections }\end{array}$ & $\begin{array}{l}\text { Mild steel I beams approximately } 150 \mathrm{~mm} \\
\text { deep and approximately } 19 \mathrm{~kg} / \mathrm{m}\end{array}$ & 0.63 & $\mathbf{X}$ & $\mathbf{X}$ & $\mathbf{X}$ \\
\hline Sheet metal roofing & $\begin{array}{l}\text { Twin skin roofing panel comprising colour } \\
\text { coated steel or aluminium profiled sheeting } \\
\text { outer layer, 100mm insulation, internal liner } \\
\text { sheet, }\end{array}$ & 0.72 & $\mathbf{X}$ & $\mathbf{X}$ & \\
\hline Metal storage tank & $\begin{array}{l}\text { Metal storage tank capacity } 15 \mathrm{~m} 3 \text {, } \\
\text { thickness of steel, } 5 \mathrm{~mm} \text {, typical size, } 3.75 \mathrm{~m} \\
\text { x } 2 \mathrm{~m} \times 2 \mathrm{~m}\end{array}$ & 0.96 & $\mathbf{X}$ & $\mathbf{X}$ & $\mathbf{X}$ \\
\hline Cast iron drain pipe & $\begin{array}{l}\text { 150mm diameter with mechanical coupling } \\
\text { joints }\end{array}$ & 1.58 & $\mathbf{X}$ & $\mathbf{X}$ & $\mathbf{X}$ \\
\hline Copper pipe & $\begin{array}{l}15 \mathrm{~mm} \text { copper pipe suitable for mains } \\
\text { pressure water. }\end{array}$ & 0.99 & $\mathrm{X}$ & $\mathrm{X}$ & \\
\hline Electric pump & $\begin{array}{l}\text { Electric pump for pumping water, } \\
\text { temperature range, } 5-80 \mathrm{oC} \text {, flow rate } 10 \\
\text { litres/second, head pressure, } 150 \mathrm{~Pa}\end{array}$ & 1.41 & & $\mathbf{X}$ & $\mathbf{X}$ \\
\hline Electric fan & $\begin{array}{l}\text { Electric exhaust fan for interior installation, } \\
\text { flow rate, } 1,000 \text { litres/ second, head } \\
\text { pressure, } 250 \mathrm{~Pa}\end{array}$ & 1.60 & & $\mathbf{X}$ & \\
\hline $\begin{array}{l}\text { Air-conditioning } \\
\text { equipment }\end{array}$ & $\begin{array}{l}\text { Air cooled liquid chiller, refrigerant 407C; } \\
\text { reciprocating compressors; twin circuit; } \\
\text { integral controls cooling load 400kW }\end{array}$ & 1.49 & $\mathbf{X}$ & $\mathbf{X}$ & \\
\hline Stand-by generator & $\begin{array}{l}\text { Diesel generating set for stand-by use, three } \\
\text { phase 24V DC, 250KVA output }\end{array}$ & 0.79 & & $\mathbf{X}$ & \\
\hline Solar collector & $\begin{array}{l}\text { PV solar panels peak output } 650 \mathrm{~W} \text {, supply } \\
\text { panels only, typically } 4.5 \mathrm{~m} 2 \text { total area }\end{array}$ & 0.77 & $\mathbf{X}$ & $\mathbf{X}$ & $\mathbf{X}$ \\
\hline Electricity & Typical average commercial tariff & 2.21 & $\mathbf{X}$ & $\mathbf{X}$ & $\mathbf{X}$ \\
\hline \multicolumn{2}{|c|}{ Construction equipment } & 0.28 & & & \\
\hline $\begin{array}{l}\text { Wheeled loader } \\
\text { and excavator }\end{array}$ & $\begin{array}{l}\text { 1.0m3 loader capacity, } 2.35 \mathrm{~m} \text { wide shovel, } \\
6.0 \mathrm{~m} \text { max. dig depth }\end{array}$ & 0.29 & & & \\
\hline Tracked tractor & Crawler dozer $159 \mathrm{~kW}$ with 'U’ blade & 0.35 & & & \\
\hline Skid steer loader & $\begin{array}{l}\text { Tipping load, 2,000kg, travel speed, } \\
11.1 \mathrm{~km} / \mathrm{hr}\end{array}$ & 0.31 & & & \\
\hline $\begin{array}{l}\text { Tandem vibrating } \\
\text { roller }\end{array}$ & Self propelled 5 tonne double vibratory & 0.26 & & & \\
\hline $\begin{array}{l}\text { Compact track } \\
\text { loader }\end{array}$ & $\begin{array}{l}\text { Rated operating capacity, } 864 \mathrm{~kg} \text {, travel } \\
\text { speed, } 11.4 \mathrm{~km} / \mathrm{hr}\end{array}$ & 0.34 & & & \\
\hline \multicolumn{2}{|c|}{ Construction labour } & 0.19 & & & \\
\hline $\begin{array}{l}\text { General (unskilled) } \\
\text { labourers }\end{array}$ & $\begin{array}{l}\text { Workers that undertake simple and routine } \\
\text { tasks in support of activities performed by } \\
\text { more skilled workers. They have usually } \\
\text { received little or no formal training }\end{array}$ & 0.24 & & & \\
\hline Bricklayer & \multirow{6}{*}{$\begin{array}{l}\text { These workers have received training in } \\
\text { their trades comprising one or more of } \\
\text { apprenticeships, on the job training or } \\
\text { training in a technical college or similar } \\
\text { institution }\end{array}$} & 0.13 & & & \\
\hline Plumber & & 0.14 & & & \\
\hline Carpenter & & 0.11 & & & \\
\hline $\begin{array}{l}\text { Structural steel } \\
\text { worker }\end{array}$ & & 0.13 & & & \\
\hline Electrician & & 0.19 & & & \\
\hline $\begin{array}{l}\text { Machine } \\
\text { (equipment) } \\
\text { operator }\end{array}$ & & 0.36 & & & \\
\hline
\end{tabular}

